\title{
TROPIDOGASTER BLAINVILLII DUMÉRIL \& BIBRON, 1837 (REPTILIA, SAURIA): PROPOSED SUPPRESSION UNDER THE PLENARY POWERS. Z.N.(S.) 1860
}

By Richard Etheridge (Department of Zoology, San Diego State College, San Diego, California, U.S.A.)

Two genera of lizards in the family Iguanidae occur on the island of Madagascar (Malagasy Republic). One of these contains a single species that has been known under the name Chalarodon madagascariensis since the description of that genus and species by Peters in 1854. Seventeen years earlier Duméril \& Bibron (1837) described Tropidogaster blainvillii, based on a specimen in the Paris Museum from an unknown locality. Examination of the syntypes of Chalarodon madagascariensis and the holotype of Tropidogaster blainvillii shows that the former is a synonym of the latter. The object of the present application is to request the International Commission on Zoological Nomenclature to use its plenary powers for the purpose of suppressing the name Tropidogaster blainvillii Duméril \& Bibron, 1837, and to validate the name Chalarodon madagascariensis Peters, 1854. The relevant history of this case follows.

2. In 1837, Duméril \& Bibron described a new genus and species of iguanid lizard, Tropidogaster blainvillii, based on a specimen in the Muséum National d'Histoire Naturelle, Paris (No. 6869). The geographic origin of the specimen was unknown.

3. Fitzinger (1843: 59) listed this species in the combination Ptychosaurus (Tritropis) Blainvillii, and (p. 16) designated Blainvillii as the type-species of the subgenus Tritropis. The range was said to be "America".

4. Peters (1854:616) described a new genus and species of iguanid lizard, Chalarodon madagascariensis, based on five specimens now in the Zoologischen Museum der Humbold Universität, Berlin (Nos. 4360 (2), 5617, 9214 (2)), from "Madagascar (St. Augustins-Bay)". This name has been in continuous usage for this well known Malagasy iguanid lizard since its description.

5. In addition to listing Peter's Chalarodon madagascariensis, Boulenger (1885 : 178) included Duméril \& Bibron's species in the combination "Tropidurus? blainvillii". Tropidurus is a common, large genus of iguanid lizards that inhabits South America and the Galápagos Islands. However, Boulenger wrote "——? " for the range of blainvillii.

6. In their checklist of South American lizards Burt \& Burt (1933:45) listed the species as Tropidurus blainvillii, and gave "South America" as its range.

7. I have examined the holotype of Tropidogaster blainvillii and the syntypes of Chalarodon madagascariensis and find them to be identical in all essential details. Distinctive characteristics that permit certain identification 
are the tricarinate ventral body scales, and the jet black spot that overlies the interparietal scale.

8. About 64 genera and 700 species of lizards in the family Iguanidae occupy the New World; one monotypic genus occurs on Fiji and the Tonga Islands, and two genera (one monotypic, one with six species) occur on Madagascar and the Comores Archipelago. The disjunct occurrence of the Malagasy iguanid genera is therefore of particular interest to zoogeographers, all of whom (e.g. Darlington, $1957: 212$ ) have always used the name Chalarodon madagascariensis. This name has also always been used in faunal lists (e.g. Angel, 1942; Mertens, 1933; Barbour, 1918), and works on anatomy (e.g. Blanc, 1965).

9. In view of the fact that at no time since the description of Tropidogaster blainvillii has that name been applied to the Malagasy iguanid, and since Chalarodon madagascariensis has been in continuous usage for over 100 years, I therefore request the International Commission on Zoological Nomenclature to take the following actions:

(1) to use its plenary powers to suppress the following names for the purposes of the Law of Priority but not for those of the Law of Homonymy:

(a) the generic name Tropidogaster Duméril \& Bibron, 1837 (: 329);

(b) the subgeneric name Tritropis Fitzinger, 1843 (: 59);

(c) the specific name blainvillii Duméril \& Bibron, 1837 (: 300) as published in the binomen Tropidogaster Blainvillii;

(2) to place the generic name Chalarodon Peters, 1854 (:616), (gender: masculine), type-species by monotypy, Chalarodon madagascariensis Peters, 1854 (: 616), on the Official List of Generic Names in Zoology;

(3) to place the specific name madagascariensis Peters, 1854 (:616), as published in the binomen Chalarodon madagascariensis (type-species of Chalarodon Peters, 1854) on the Official List of Specific Names in Zoology;

(4) to place the generic names suppressed under the plenary powers in (1) (a) and (b) above on the Official Index of Rejected and Invalid Generic Names in Zoology;

(5) to place the specific name suppressed under the plenary powers in (1) (c) above on the Official Index of Rejected and Invalid Specific Names in Zoology.

\section{Literature Cited}

ANGel, F. 1942. Les Lézards de Madagascar. Mém. l'Acad. Malagach, Tananarive Fas. 36, pp. 1-193

Barbour, T. 1918. Vertebrata from Madagascar, Amphibians and Reptiles. Bull. Mus. Comp. Zool., Harvard, Cambridge (Massachusetts), Vol. 61, No. 14, pp. $479-489$

Blanc, C. P. 1965. Études sur les Iguanidae de Madagascar. I. Le squelette de Chalarodon madagascariensis Peters, 1854. Mém. Mus. Nat. d'Hist. Nat., (N.S.), A. Zool., Vol. 33, No. 3, pp. 93-146

Boulenger, G. A. 1885. Catalogue of the lizards in the British Museum (Natural History), London, Ed. 2, Vol. 2, xiii + 497 pp. 
Burt, C. E., and Burt, M. D. 1933. A preliminary check list of the lizards of South America. Trans. Acad. Sci. St. Louis, Vol. 27, No. 1, v + 104 pp.

DARLINGTON, P. J. 1957. Zoogeography: the geographical distribution of animals. John Wiley \& Sons, Inc., New York, xi $+675 \mathrm{pp}$,

DumérIL, A. M. C., and BIBRoN, G. 1837. Erpétologie générale ou histoire naturelle complète des reptiles, Paris, Vol. 4 , ii $+571 \mathrm{pp}$.

Fitzinger, L. 1843. Systema Reptilium, Amblyglossae, Vienna, Vol. 1, $106+$ vi pp.

Mertens, R. 1933. Die Reptilien der Madagaskar-Expedition Prof. Dr. H. Bluntschili. Senckenbergiana, Frankfurt a.M., Vol. 15, pp. 260-274

Peters, W. 1854. Diagnosen neuer Batrachier, welche zusammen mit der fröher (24. Juli und 17. August) gegeben Übersicht der Schlangen und Eidechsen mitgethelt werden. Monat. König. Akad. Wiss. Berlin, pp. 614-628 


\section{$2 \mathrm{BHL}$ Biodiversity Heritage Library}

Etheridge, Richard. 1969. "Tropidogaster blainvillii Dumeril \& Bibron, 1837 (Reptilia, Sauria): proposed suppression under the plenary powers. Z.N.(S.) 1860." The Bulletin of zoological nomenclature 25, 224-226.

https://doi.org/10.5962/bhl.part.24004.

View This Item Online: https://www.biodiversitylibrary.org/item/44467

DOI: https://doi.org/10.5962/bhl.part.24004

Permalink: https://www.biodiversitylibrary.org/partpdf/24004

\section{Holding Institution}

Natural History Museum Library, London

\section{Sponsored by}

Natural History Museum Library, London

\section{Copyright \& Reuse}

Copyright Status: In copyright. Digitized with the permission of the rights holder.

License: http://creativecommons.org/licenses/by-nc-sa/3.0/

Rights: https://biodiversitylibrary.org/permissions

This document was created from content at the Biodiversity Heritage Library, the world's largest open access digital library for biodiversity literature and archives. Visit BHL at https://www.biodiversitylibrary.org. 